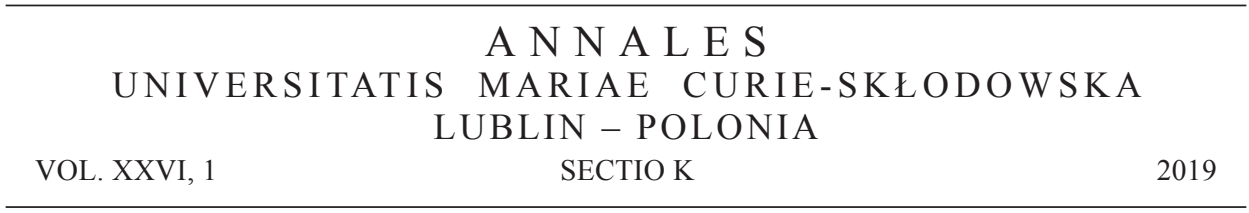

Akademia Finansów i Biznesu. Instytut Stosunków Międzynarodowych

ANNA GRZYWACZ

ORCID: https://orcid.org/0000-0002-2214-7199

\title{
Retoryka i praktyka: polityka Indonezji wobec Zachodu
}

Rhetoric and Practice: Foreign Policy of Indonesia Towards the West

\begin{abstract}
ABSTRAKT
Celem artykułu jest przedstawienie stosunku państwa indonezyjskiego do państw Zachodu w wymiarze retorycznym i praktycznym. W pracy podjęto próbę odpowiedzi na pytanie o to, jak postrzeganie Zachodu wpływało na politykę zagraniczną Indonezji wobec państw zachodnich. W tekście zweryfikowana zostanie hipoteza stanowiącą, że politykę tego państwa charakteryzuje dualność: wieloletnia krytyka Zachodu miała charakter przede wszystkim deklaratywny, a więc była retoryką, nie zaś praktyką. W artykule wykorzystano analizę treści do oceny retoryki, następnie porównano narrację z działaniami politycznymi. Artykuł podzielono na cztery części. Po wstępie omówiona została polityka Indonezji przed i po rozpoczęciu procesu demokratyzacji w 1998 roku. Pracę kończy podsumowanie. Przyjęcie długiej perspektywy czasowej pozwala ukazać zmiany zachodzące w polityce Indonezji - od państwa antyzachodniego po państwo prozachodnie w retoryce i praktyce.
\end{abstract}

Słowa kluczowe: Indonezja, polityka zagraniczna, Zachód, retoryka

\section{WSTĘP}

Proces dekolonizacji w Azji Południowo-Wschodniej, który rozpoczął się po zakończeniu II wojny światowej, nie oznaczał zakończenia dominacji państw Zacho$\mathrm{du}^{1} \mathrm{w}$ tym regionie. Państwa europejskie próbowały odzyskać swoją silną pozycję

1 Zachód w niniejszym artykule jest rozumiany jako państwa zachodnioeuropejskie oraz Stany Zjednoczone Ameryki, a więc państwa, które były silnie zaangażowane w tworzenie systemu międzyna- 
polityczną. Relacje kolonialne zastąpiono nowymi formami, a obie strony cały czas łączyły programy pomocy rozwojowej, relacje gospodarcze czy współpraca naukowa. Stosunki między byłymi kolonizatorami a krajami kolonizowanymi zaczęto kształtować na innej płaszczyźnie, a państwa pokolonialne doświadczały trudności wynikających z dziedzictwa kolonializmu. Wieloletnia obecność państw europejskich spowodowała, że tożsamość, struktura, tradycja, kultura czy sam system organizacji politycznej państw kolonizowanych został ukształtowany na bazie tych doświadczeń [zob. Anderson 1999, 1990]. Podobnie jak w przypadku innych państw Indonezja próbowała się odnaleźć w tym „nowym świecie”, starając się uporać ze swoją tożsamością narodową i międzynarodową².

Indonezja była holenderską kolonią przez ponad 300 lat. System społeczny i polityczny Indonezji był więc kształtowany na bazie doświadczeń kolonialnych, które są źródłem i przyczyną wielu problemów etnicznych, kulturowych czy politycznych lub przynajmniej wiele z nich swoje korzenie ma w tej właśnie historii [Vickers 2005: 2-3; zob. też Reid 1974]. Kwestia kolonializmu i walki z imperializmem była jedną z najczęściej pojawiających się w debacie politycznej po ogłoszeniu niepodległości przez Indonezję w sierpniu 1945 r. i zakończeniu rywalizacji z Holandią w 1949 r. [Reid 1974: 7]. Inną kwestią jest to, że chociaż epoka kolonializmu oficjalnie się zakończyła, to wiele państw tak zachodnich, jak i państw tzw. Trzeciego Świata żywią przekonanie, że nadal odczuwalne są jego skutki zarówno polityczne, jak i kulturowe [zob. np. Krishna 2009].

Podjęcie tematyki polityki zagranicznej Indonezji w kontekście postrzegania i praktyki politycznej wobec Zachodu stanowi próbę uzupełnienia analiz związanych z badaniem szeroko rozumianej polityki zagranicznej tego państwa. Aktywność międzynarodowa Indonezji jest szeroko opisana w literaturze anglojęzycznej ${ }^{3}$, szczególnie w pracach takich autorów, jak: Dewi Fortuna Anwar [1994, 2009, 2010, 2011], Rizal Sukma [1995, 2003, 2009, 2011], Anne Marie Murphy [2012], Michael Leifer [1983], Leo Suryadinata [1996], Amitav Acharya [2014], Ronald Emmers [2014] czy Jürgen Rüland [2010, 2014, 2017]. Zdecydowanie mniej jest prac polskojęzycznych [Grzywacz 2014; Gwóźdź 2015]. Z tego powodu artykuł stanowi uzupełnienie tej tematyki, jednocześnie zwracając uwagę na problematykę, która jest niedoceniana w literaturze.

rodowego po II wojnie światowej, a także posiadające swoje kolonie lub silnie zaangażowane w regionie Azji i Pacyfiku, a po zakończeniu zimnej wojny państwa, które były lub są zaangażowane w promocję demokracji i praw człowieka.

2 Tożsamość jest kategorią tradycyjnie zarezerwowaną dla nauk antropologicznych i przynależną człowiekowi lub grupie społecznej. Niemniej jednak coraz częściej wykorzystuje się ten termin w innych naukach i w odniesieniu do innych podmiotów. W tej pracy przyjmuje się założenie, że państwo może mieć swoją tożsamość.

3 Z tego powodu nie można się zgodzić ze stwierdzeniem Damiana Gwoździa, który stwierdził, że podjął się analizy polityki zagranicznej Indonezji, gdyż występuje ,pewnego rodzaju przemilczenie tego zagadnienia ze strony światowych ośrodków naukowych” [Gwóźdź 2015: 80]. 
Celem artykułu jest przedstawienie stosunków Indonezji z państwami Zachodu przez próbę odpowiedzi na pytanie, jak postrzeganie Zachodu wpływało na politykę zagraniczną Indonezji wobec państw zachodnich. W tekście przyjęto założenie, że aktywność Indonezji w początkowym okresie formowania państwa charakteryzowała się postawą antyzachodnią, zaś polityka w znacznym stopniu była formowana przez obawy o rekolonizację regionu. W połowie lat 60 . XX wieku polityka została całkowicie przewartościowana. Zachód zaczął być postrzegany przez rząd indonezyjski jako najlepsze źródło pomocy finansowej, z tego powodu relacje między stronami układały się relatywnie dobrze. Po zakończeniu zimnej wojny państwa zachodnie mogły już swobodniej krytykować Indonezję za brak demokracji czy nieprzestrzeganie praw człowieka, przestała ona być bowiem już kluczowym partnerem. Zasadnicze zmiany zaszły w 1998 r. po odejściu od władzy Suharto. Przemiany demokratyczne uczyniły z Indonezji nie tylko wartościowego partnera dla państw zachodnich, ale sprawiły również, że państwo to, mimo że krytycznie podchodzi do pewnych rozwiązań narzuconych przez Zachód, to posługuje się tymi samymi wartościami co państwa zachodnie oraz prowadzi podobną politykę, m.in. w kwestii promowania demokracji. W pracy zweryfikowana zostanie hipoteza stanowiąca, że politykę tego państwa charakteryzuje dualność: wieloletnia krytyka Zachodu miała charakter przede wszystkim deklaratywny, a więc była retoryką, nie przekładała się zaś na praktykę. W artykule wykorzystano analizę treści do oceny retoryki (na podstawie najważniejszych przemówień prezydentów Indonezji), następnie porównano narrację z działaniami politycznymi przed i po demokratyzacji Indonezji. Artykuł podzielono na cztery części. Po wstępie omówiono politykę Indonezji przed i po rozpoczęciu procesu demokratyzacji w 1998 roku. Pracę kończy podsumowanie. Przyjęcie długiej perspektywy czasowej pozwala ukazać zmiany zachodzące w polityce Indonezji - od państwa antyzachodniego po państwo prozachodnie w retoryce i praktyce.

\section{CHARAKTERYSTYKA POLITYKI ZAGRANICZNEJ INDONEZJI DO 1998 ROKU}

Polityka zagraniczna Indonezji opierała się na dwóch podstawowych zasadach antikolonialisme (antykolonializmie) i niezmiennej do dzisiaj politik luar negeri bebas aktif (,niezależnej i aktywnej polityce zagranicznej”) [Sukma 1995: 305-306]. Pierwsze założenia polityki zagranicznej, które powstały po 1945 r., zostały zdefiniowane przez Mohammada Hattę - pierwszego wiceprezydenta Indonezji - który stwierdził, że najlepszą polityką jest taka, która nie uczyni Indonezji obiektem międzynarodowego konfliktu, a państwo będzie niezależne na tyle, aby decydować samo o sobie. Stwierdzenie to stało się podstawą funkcjonowania Indonezji w stosunkach międzynarodowych. Mohammad Hatta starał się sformułować jasne wytyczne dla polityki zagranicznej. Założenia te przedstawił w swoim przemówieniu „Mendayung Antara Dua Karang” (,wiosłowanie między dwoma rafami”) wygłoszonym 2 września 1948 r. Niezależna i aktywna polityka zagraniczna Indonezji według niego miała być oparta na: 
1) ideologii państwowej, czyli Pancasili; 2) ochronie interesu narodowego przedstawionego w konstytucji; 3) ochronie interesu narodowego przez niezależną i aktywną politykę; oraz 4) pragmatyzmie i racjonalności [Sukma 1995: 305-306].

Podstawowymi celami polityki zagranicznej było: 1) wspieranie rozwoju narodowego z priorytetowym traktowaniem kwestii ekonomicznych; 2) utrzymanie wewnętrznej i regionalnej stabilności zgodnie z interesem narodowego rozwoju; a także 3) ochrona integralności terytorialnej Indonezji [Indonesia s... 2007: 132].

Indonezyjskie przywiązanie do zasady antykolonializmu oraz koncepcji ,polityki niezależnej i aktywnej" było wynikiem walki o niepodległość, którą ogłosił ruch nacjonalistyczny w latach 40. XX wieku. Indonezja ze względu na trudną sytuację polityczną potrzebowała międzynarodowego uznania. Niedługo po deklaracji niepodległości rozpoczął się konflikt z Holandią, która dążyła do rekolonizacji Indonezji. W latach rewolucji narodowej szczególnie ważny wydawał się czynnik zewnętrzny. Walka z Holendrami nie zyskała jednoznacznego poparcia najsilniejszych państw, przede wszystkim Stanów Zjednoczonych Ameryki, które wspierały Holandię aż do 1948 r. [Drakeley 2005: 51-82]. W tym czasie narodziło się przekonanie, że Indonezja musi się stać samodzielna w dążeniu do niepodległości, co najlepiej osiągnąć przez połączenie perjuangan (,walki”) i diplomasi („dyplomacji”) [Sukma 2003: 46]. Już wtedy zaczęto krytykować Stany Zjednoczone Ameryki. Krytyka wzmocniona została w latach 60. XX wieku, gdy okazało się, że Centralna Agencja Wywiadowcza USA (Central Intelligence Agency - CIA) miała brać udział w obaleniu rządów Sukarno (pierwszego prezydenta Indonezji) w 1965 r. i masakrach na komunistach z lat 1966-1967. Wydarzenia te ukształtowały przekonanie, że Stany Zjednoczone Ameryki wspierają rządy autorytarne, krwawe, silne, skorumpowane i nieuczciwe [Kay 2005: 9].

Mohammad Hatta [1961: 10] napisał artykuł, w którym przedstawił politykę zagraniczną jako będącą, ,wolną od wpływów bloku zachodniego i wschodniego, tak politycznie, jak i ideologicznie". Pierwszy wiceprezydent Indonezji wyrażał wielokrotnie swoje ubolewanie z niezrozumienia problemu kolonializmu przez państwa Zachodu, które wykorzystują ten element rywalizacji politycznej do utrzymywania swojej dominującej pozycji w systemie międzynarodowym [Hatta 1961: 10-14].

Rządy Sukarno, pierwszego prezydenta Indonezji, charakteryzowały się postawą antyzachodnią. Sukarno w swych pierwszych przemowach posługiwał się dość często hasłem imperializmu. Sama idea polityki zagranicznej i aktywnej w jego wydaniu koncentrowała się na tym, aby zapewnić realizację interesów narodowych Indonezji, nie popadając jednocześnie w uzależnienie od potęg międzynarodowych.

4 W połowie lipca 1945 r. zdecydowano, że Indonezja będzie się opierać na ideologicznej formule zaproponowanej przez Sukarno w przemówieniu z 1 czerwca 1945 r. Sukarno próbował przekonać, że niepodległe państwo indonezyjskie powinno bazować na pięciu zasadach: 1) wierze w jednego Boga (Ketuhanan); 2) zasadzie humanitaryzmu (kemanusiaan); 3) nacjonalizmie (kebangsaan); 4) zasadzie konsensusu lub demokracji (mufakat atau demokrasi); 5) sprawiedliwości społecznej (kesejehteraan sosial). 
$\mathrm{Z}$ tego powodu powstały takie instytucje, jak Ruch Państw Niezaangażowanych (Non-Aligned Movement - NAM) założony w 1961 r. [Kay 2005: 8-9].

W roku 1960 w czasie przemówienia w Dniu Niepodległości Sukarno rozciągnął ideę równoważenia ekonomicznych relacji: niezależna i aktywna polityka miała na celu ukształtowanie stosunków gospodarczych tak, aby nie opierały się one ani na Zachodzie, ani na Wschodzie [Weinstein 2007: 167]. Wydaje się, że Sukarno położył zbyt duży nacisk na kwestię antykolonializmu, ignorując nieco ideę niezależności. Jego zaangażowanie w konfrontację z Malezją w 1963 r. po ogłoszeniu decyzji o powstaniu Federacji czy też opozycja wobec Zachodu nie zdobyły poparcia społeczeństwa indonezyjskiego [Sukma 1995: 310].

W latach 60. XX wieku linia podziału między wyzyskującymi a wyzyskiwanymi została zarysowana w innym miejscu, nie była to już linia Wschód-Zachód, ale konfrontacja między ustanowionymi a wschodzącymi siłami. Zgodnie z opiniami Sukarno, imperializm cały czas był zagrożeniem dla rozwijającego się państwa. Zgodnie z jego poglądami, środowisko międzynarodowe było miejscem rywalizacji między „siłami starego porządku” (OLDEFOS) a „,nowymi wyłaniającymi się siłami” (NEFOS). Konflikt między tymi dwoma blokami miał doprowadzić do upadku tych pierwszych. Następnie zaczął promować to, co zostało przez niego nazwane osią Dżakarta-Phnom Penh-Pekin-Pjongjang. Indonezja, Kambodża, Chiny i Korea Północna miały stworzyć platformę współpracy, która wzmocniłaby te państwa na arenie międzynarodowej [Fic 2005; George 2010]. Kolonializm i neokolonializm mogły zostać pokonane przez te właśnie państwa w drodze realizacji polityki wymierzonej przeciw państwom Zachodu [Morfit 1981: 838-851].

Jak już wspomniano, indonezyjska polityka zagraniczna w latach 50. i 60. XX wieku charakteryzowała się przede wszystkim antyimperializmem i antykolonializmem. Pomoc, której potrzebowały państwa rozwijające się, była postrzegana przez Sukarno jako sposób na utrzymanie zależności między państwami. Uznał on, że Stany Zjednoczone Ameryki „mogą pójść do diabła ze swoją pomocą” [Mortimer 2006: 268]. Wraz ze wzrostem gospodarczym powrócił problem uzależnienia ekonomicznego od państw wysoko rozwiniętych. Oznacza to więc, że mimo krytyki okresu rządów Sukarno pod względem stosunku do państw zachodnich Indonezja współpracowała z tymi państwami. Dane dotyczące importu i eksportu Indonezji z blokiem wschodnim i zachodnim w latach 60 . XX wieku pokazują, że mimo retoryki antyzachodniej Indonezja ukierunkowana przede wszystkim na rozwój gospodarczy utrzymywała kontakty z państwami zachodnimi [Weinstein 2007: 212-225].

Pierwszy prezydent Indonezji, niezadowolony z ówczesnego systemu międzynarodowego, zawiesił w 1965 r. członkostwo Indonezji w Organizacji Narodów Zjednoczonych (ONZ) i innych instytucjach. W połowie lat 60 . trudności gospodarcze spowodowały, że Indonezja zaczęła potrzebować wsparcia finansowego USA, Europy Zachodniej, Japonii i instytucji międzynarodowych. Z tych powodów Suharto (drugi prezydent Indonezji) ,powrócił” w 1966 r. do ONZ, zaś rok później do Międzynarodowego Funduszu Walutowego (MFW) i Banku Światowego (BŚ) [Wie 
2002: 195]. W czasie rządów Suharto polityka zagraniczna się zmieniła. Indonezja - według niego - potrzebowała pomocy Zachodu, bez tego nie byłaby w stanie się rozwijać, nie umocniłaby się i nie stała silnym państwem. Chociaż Suharto nie miał uregulowanych wszystkich kwestii terytorialnych, w dyskursie politycznym zaprzestano podkreślania kwestii suwerenności i niezależności państwa [Weinstein 2007: 19-20]. Początek rządów Suharto charakteryzował się przewartościowaniem polityki Indonezji - rezygnacją z konfrontacyjnej postawy wraz z prozachodnim nastawieniem, które pozwoliłoby Indonezji na dynamiczny rozwój gospodarczy. Polityka Suharto charakteryzowała się zasadniczo trzema cechami: 1) silnym antykomunizmem; 2) zaangażowaniem w rozwój i stabilność państwową; 3) pragmatycznym spojrzeniem na sprawy międzynarodowe [Suryadinata 2005].

Zmagania polityczne Indonezji Franklin B. Weinstein [2007: 30] podsumował stwierdzeniem, że to dylemat zależności odgrywał centralną rolę w indonezyjskiej polityce zagranicznej. Znalezienie sposobu na korzystanie z pomocy państw rozwiniętych, przy jednoczesnym nieuzależnianiu się było pytaniem, na które oba rządy próbowały znaleźć odpowiedź. Nawet jeśli Indonezja musiałaby poświęcić ideały, to pojawiał się problem rodzaju modelu gospodarczego, który okazałby się najefektywniejszy w warunkach indonezyjskich. Próba rozstrzygnięcia tego dylematu stała się więc najważniejszą kwestią. Zanim jednak polityka zagraniczna mogła być prowadzona w swej „idealnej formie polityki aktywnej i niezależnej”, należało poprawić sytuację wewnętrzną państwa, przede wszystkim przez jej rozwój gospodarczy - pembangunan - co stało się podstawowym celem polityczno-społecznym Suharto [Weinstein 2007: 206-241].

Zasada sprawiedliwości społecznej przedstawiona w Pancasili i potrzeba dobrobytu społeczeństwa wyrażona w konstytucji były podstawami, na których oparto te założenia. Z tych powodów rząd Nowego Porządku (Orde Baru, czyli Nowy Porządek - to okres sprawowania władzy przez Suharto, 1967-1998) podkreślał zasadę, że polityka zagraniczna powinna chronić i realizować interes narodowy, postrzegany wtedy głównie w kategoriach ekonomicznych. Elementem pembangunan $\mathrm{w}$ polityce zagranicznej tego okresu było przede wszystkim przeorientowanie się na pomoc rozwojową. Takie podejście przybliżyło Indonezję do lepiej radzącego sobie gospodarczo bloku Zachodu, z którego ta pomoc mogła przyjść, ale oznaczało również zmianę polityki z radykalnej na bardziej racjonalną. W rezultacie, według Rizala Sukmy [1995:310-312], polityka zagraniczna tego okresu nie wydaje się ani aktywna, ani niezależna. Można jej za to przypisać pragmatyzm.

Przejawy większej aktywności w polityce zagranicznej można dostrzec w kilku inicjatywach polityki zagranicznej. Po okresie raczej pasywnej polityki w latach 60 . i 70. XX wieku pierwszym wydarzeniem, które można uznać za „powrót Indonezji” było upamiętnienie w kwietniu 1985 r. 30. rocznicy Konferencji Azji i Afryki jako symbol zwrotu w stronę polityki aktywnej po dekadach „nieobecności”. Tym większe miało to znaczenie, gdyż było pewnym komunikatem nawiązującym do historii Indonezji, przypominającym, że państwo to odgrywało rolę lidera w ruchu 
państw tzw. Trzeciego Świata i chciałoby odzyskać dawną pozycję, tym bardziej że „pokolenie Bandungu” odegrało istotną rolę polityczną, najpierw inicjując powstanie ruchu państw neutralnych, potem tworząc elity polityczne. Indonezji zależało na uzyskaniu przewodnictwa w NAM - choć przegrała rywalizację z Nikaraguą w 1989 r., to została wybrana do przewodnictwa na lata 1992-1995 [Reid 2012: 120]. Dżakarcie zależało na powrocie do wizerunku państwa-założyciela tego ruchu [zob. też Mozingo 2007].

\section{ZACHÓD W POLITYCE INDONEZJI PO 1998 ROKU}

Po zakończeniu zimnej wojny pierwsze wytyczne dotyczące polityki zagranicznej pojawiły się w 1993 r., a więc jeszcze w czasie trwania Nowego Porządku. Następne przedstawiono w 2009 r. Głównymi obszarami zainteresowania Indonezji pozostaje ASEAN (Stowarzyszenie Narodów Azji Południowo-Wschodniej) jako najważniejsza dla tego państwa organizacja, ale także integracja rynków ekonomicznych, poprawa relacji z państwami zachodnimi, promowanie demokracji i praw człowieka oraz idea równoważenia przepływów kapitałowych i technologicznych między Północą a Południem. Joko Widodo, prezydent Indonezji od 2014 r. wskazał również na takie aspekty, jak: promowanie tożsamości Indonezji jako państwa archipelagowego, wzmocnienie dyplomacji ekonomicznej i państwa średniego zasięgu (middle power diplomacy) oraz zaangażowanie w region Indopacyficzny [Connelly 2015: 5-6].

Zakończenie zimnej wojny nie zmieniło w sposób istotny podejścia i postrzegania państw zachodnich przez społeczeństwo indonezyjskie. Ważnym momentem, który ukształtował tożsamość narodową i międzynarodową Indonezji, jest proces demokratyzacji zapoczątkowany w wyniku kryzysu finansowego. Państwo to jest dzisiaj największą muzułmańską demokracją na świecie. Od 1998 r. Indonezja umacnia swoją pozycję w systemie stosunków międzynarodowych zarówno w wymiarze regionalnym, jak i globalnym, prowadząc coraz aktywniejszą politykę zagraniczną. Konsolidacja demokracji, relatywnie szybka odbudowa gospodarki po kryzysie, uregulowanie konfliktu z Timorem Wschodnim oraz ustabilizowanie sytuacji wewnętrznej $\mathrm{w}$ tym państwie przyczyniło się do ukształtowania nowej tożsamości międzynarodowej Indonezji, z wyszczególnieniem islamu i demokracji jako jej ważniejszych cech. Między innymi na tej podstawie jest kształtowana polityka zagraniczna Indonezji. Założenia dotyczące polityki powstają na podstawie wewnętrznej debaty dotyczącej roli Indonezji w stosunkach międzynarodowych. Jaki kształt przybierała ta dyskusja, było zależne od kontekstu historyczno-politycznego, w którym Indonezja się znajdowała.

Po 1998 r. i wprowadzeniu systemu demokratycznego Indonezji poświęcało się więcej uwagi, ze względu na rolę, jaką mogłoby odegrać to państwo w kwestii łączenia demokracji z religią islamską. W 2009 r. pełniąca wówczas funkcję sekretarza stanu 
USA Hilary Clinton w jednej z przemów o Indonezji stwierdziła, że jeśli „,chcesz zobaczyć czy islam, demokracja, nowoczesność i prawa kobiet mogą współistnieć, jedź do Indonezji” [za: Hughes 2010: 75]. Demokratyzacja miała silny i podstawowy wpływ na politykę zagraniczną Indonezji, prowadząc do zmian w zakresie wartości i interesów kształtujących aktywność zewnętrzną tego państwa [Acharya 2014; por. Karim 2017]. W czasie rządów Suharto Indonezja opierała swoją siłę polityczną na ASEAN oraz rozwoju gospodarczym; współcześnie często w dyskursie politycznym jest podkreślany fakt współistnienia demokracji i islamu [Anwar 2011; Azra 2006; por. Bayat 2007]. Demokratyzacja ponadto stała się głównym czynnikiem poprawiającym stosunki z Europą i Stanami Zjednoczonymi Ameryki.

Stany Zjednoczone Ameryki i państwa europejskie są krytykowane za nieprzestrzeganie wartości demokratycznych i praw człowieka, co wedle zwolenników relatywizmu i przeciwników ,zachodniej uniwersalności” podważa nie tylko uniwersalność tych zasad, ale również ich wiarygodność w prowadzeniu polityki promowania demokracji i wartości z nią związanych. W przypadku USA krytyka zintensyfikowała się po rozpoczęciu wojny z terroryzmem, zaś wśród państw europejskich m.in. za powiązanie współpracy ekonomicznej ze zmianami demokratycznymi czy niedostosowanie strategii, środków i metod [Youngs, Pishchikova 2013].

$\mathrm{Na}$ indonezyjskim szczeblu rządowym nie krytykuje się demokracji czy praw człowieka, wartości te bowiem stały się podstawowymi dla systemu indonezyjskiego, szczególnie od 2004 r., czyli objęcia władzy przez Susila Bambanga Yudhoyono. Krytyka jednak jest widoczna na szczeblu społecznym. Nastroje antyamerykańskie uwidaczniają się przede wszystkim ze względu na niezgodę wobec polityki USA na Bliskim Wschodzie. Jak zauważył Azyumardi Azra, „rząd Stanów Zjednoczonych zawsze poucza ludzi w rozwijających się państwach, jak Indonezja, aby były demokratyczne, hołdowały demokratycznym ideałom, przestrzegały praw człowieka i tolerancji. Jednak w tym samym czasie dokonują rzeczy, które są całkowitym przeciwieństwem demokracji. W kategoriach wizerunku i percepcji przez Indonezyjczyków, rząd amerykański stracił wiarygodność w mówieniu o demokracji” [za: Kay 2005: 1]. Politycy indonezyjscy (w tym prezydenci i ministrowie spraw zagranicznych) nie krytykują państw zachodnich, ale zauważają, że demokracja jest uniwersalna, tzn. należy do wszystkich i nie może być narzucana siłą [zob. np. Yudhoyono 2008: 5-6] $]^{5}$.

W przypadku USA zbliżenie zaowocowało podpisaniem wszechstronnej umowy o partnerstwie w listopadzie 2010 r. Jednocześnie proces ten dał szansę na wyrażanie poglądów i wpływanie na decyzje polityczne przedstawicieli rządu indonezyjskiego, spośród których wielu jest nastawionych antyamerykańsko. Dlatego też trudno jest przyjmować politykę, która jest zgodna z interesami USA, i jednocześnie dbać o opinię społeczeństwa, oba te czynniki wpływają równie mocno na relacje

5 Także wiele innych jego przemów i wypowiedzi ministrów spraw zagranicznych: Hassana Wirajudy i Marty Natalegawy. 
indonezyjsko-amerykańskie. Bliskie stosunki obu państw są wykorzystywane do wspólnego promowania demokracji, w szczególności na Bliskim Wschodzie i Afryce Północnej. Idea Indonezji będącej pomostem między światem demokracji a światem muzułmańskim jest zgodna z polityką Stanów Zjednoczonych Ameryki i leży w interesie państw Zachodu. W tym kontekście problemem staje się jednak kwestia Palestyny, szczególnie po objęciu władzy przez Donalda Trumpa. Jest to przedmiot niezgody, sprawiający, że oba te państwa stoją po przeciwległych stronach. Wraz z demokratyzacją ujawniły się również nastroje antyamerykańskie, które wcześniej były blokowane ze względu na silną władzę w Indonezji [Murphy 2012: 84]. Jest to jeden z powodów unikania jednoznacznego utożsamiania się z państwami Zachodu $\mathrm{w}$ wymiarze retorycznym.

Indonezja zaczęła być wymieniana przez niektórych polityków zachodnich jako pewien model, którego doświadczenia można by wykorzystać w procesach transformacji ustrojowych innych państw. W czasie gdy USA forsowały demokrację jako środek na terroryzm, napięcia i konflikty społeczne oraz jako sprzyjający rozwojowi ekonomicznemu, doświadczenia indonezyjskie wydają się bronić polityki USA, prowadzącej do utrzymywania Indonezji jako modelu „naśladowania” przez innych [Shekhar 2018].

Promowanie wartości demokratycznych i praw człowieka jest nowością w polityce zagranicznej wynikającej z przeprowadzonych zmian. Indonezja musiała zresztą zmienić swój wizerunek. Problem z Timorem, zamachy na Bali, wybuch i zaostrzenie konfliktów wewnętrznych wpłynęły negatywnie na wizerunek Indonezji. Dewi Fortuna Anwar, akademik i doradca w rządzie B.J. Habibie (trzeciego prezydenta Indonezji), argumentowała, że wizerunek Indonezji jako trzeciej największej demokracji na świecie musi zostać odbudowany, stać się podstawową cechą Indonezji [Murphy 2012: 89-90]. Ze względu na to, że problem ataków terrorystycznych dotykał Indonezję wielokrotnie, jak również państwo to łączy z krajami Bliskiego Wschodu więź religijna, powstała koncepcja pośredniczenia Dżakarty w dialogu Zachód-islam. Indonezja widzi siebie jako negocjatora, który ma największy potencjał w „odczarowywaniu” złego wizerunku świata muzułmańskiego, jednocześnie pokazując, że idee religijne mogą współistnieć z wartościami zachodnimi, którymi sama Indonezja się kieruje. Wydaje się jednak, że Indonezji nie udało się jeszcze skutecznie wejść w tę rolę [zob. Grzywacz 2019].

Indonezja najbardziej wykazała swoją aktywność w kwestii demokratyzacji ASEAN, odgrywając główną rolę w Forum Demokracji na Bali (Bali Democracy Forum-BDF) i naciskaniu na Mjanmę, aby zliberalizowała swój system polityczny [por. Karim 2017]. Pierwsze spotkanie w ramach BDF odbyło się w 2008 r. W 2010 r. uczestniczyły w nim 44 państwa. Obecność Chin czy Wietnamu przyczyniła się do krytyki, ale jak wyjaśniał były minister spraw zagranicznych Indonezji Hassan Wirayuda, BDF zostało stworzone jako forum i miejsce debaty o demokracji, a nie jako forum dla państw demokratycznych. Powstała również instytucja, która zajmuje się problematyką demokracji - Instytut Pokoju i Demokracji. Indonezja była główną 
siłą, która nalegała, aby w Karcie ASEAN zapisano zasady demokratyczne, dobrego zarządzania, poszanowania i ochrony praw człowieka oraz podstawowych wolności. Jest to zasadnicza zmiana, jeśli weźmie się pod uwagę fakt, że podstawową i jak do tej pory nienaruszalną zasadą ASEAN była nieingerencja w sprawy wewnętrzne [Rüland 2017]. Karta wzywała ponadto do stworzenia Międzyrządowej Komisji ASEAN ds. Praw Człowieka (ASEAN Intergovernmental Commission on Human Rights - AICHR). Indonezja opowiadała się za przekazaniem jej kompetencji do ochrony, nie zaś jedynie do promowania praw człowieka [Murphy 2012: 90-91].

Jako państwo założycielskie ASEAN Indonezja odgrywa istotną rolę w stosunkach tego ugrupowania z Unią Europejską. Jest to zarówno największe państwo Azji Południowo-Wschodniej pod względem geograficznym i ludnościowym, jak i nieformalny lider wśród państw tej organizacji. Ponadto sekretariat ASEAN znajduje się w Dżakarcie. Indonezja jest jednym z najbardziej aktywnych graczy w tej organizacji, a także promuje regionalizm poza ASEAN. Oprócz Wspólnoty Gospodarczej Azji i Pacyfiku (Asia-Pacific Economic Cooperation - APEC) kraj ten jest zaangażowany w Forum Regionalne ASEAN (ASEAN Regional Forum - ARF) i Dialog Azja-Europa (Asia-Europe Meeting - ASEM), którego UE jest członkiem.

W czasie rządów Suharto między Indonezją a Unią Europejską nie było żadnego dialogu w celu promowania wspólnych interesów. Fali wewnętrznych przemian politycznych w tym kraju towarzyszył również rozwój stosunków z regionami i organizacjami, z którymi kontakt do tej pory był ograniczony [zob. Gwóźdź 2015]. Nowe podejście Indonezji do kwestii demokracji zostało z radością przyjęte w UE, która oceniała stabilność tego państwa jako ważny element promowania pokoju i wartości demokratycznych zarówno w Azji Południowo-Wschodniej, jak i całej Azji. Wartość strategiczna wzrosła również w oczach wielu światowych mocarstw, zwłaszcza po atakach z 11 września 2001 r. Tak UE, jak i USA doceniają połączenie „względnej” demokracji, islamu i modernizacji. Indonezja odegrała aktywną rolę od początku nieformalnych spotkań ASEAN-WE (Wspólnota Europejska) w 1970 r. Rząd wziął też udział w pierwszym spotkaniu ministerialnym między ASEAN a WE, a dwa lata później był sygnatariuszem podstawowego dokumentu w odniesieniu do relacji między tymi dwoma ugrupowaniami. W celu nadzorowania interesów WE w 1979 r. ustanowiono jej przedstawicielstwo w Bangkoku. Osiem lat później rząd indonezyjski zatwierdził ustanowienie delegacji w Dżakarcie. Pogłębianie integracji - w wyniku podpisania traktatu z Maastricht i późniejszego procesu rozszerzania, które Europa przeszła po podpisaniu traktatu z Amsterdamu w 1997 r. - przyniosło poważne wyzwania dla Indonezji. Główną obawę żywiono wobec faktu, że Europa Zachodnia przekazywała pomoc rozwojową Indonezji, która mogła się zmniejszyć w wyniku rozszerzania UE [Chandra $\mathrm{i}$ in. 2010: 21-22].

Kryzys gospodarczy z 1997 r. zakwestionował związek między Dżakartą a Brukselą, również w kontekście indonezyjskiej transformacji ustrojowej, której kierunek nie był pewny. Kontrowersyjne kwestie, takie jak demokracja, dobre rządy czy prawa człowieka, które UE promuje i uznaje za najważniejsze i uniwersalne wartości, 
o których trudno było dyskutować w czasie trwania Nowego Porządku, po jego zakończeniu stały się ważnymi elementami dialogu. Przed wizytą Abdurrahmana Wahida (czwartego prezydenta Indonezji) w Brukseli w lutym 2000 r. Komisja Europejska wydała komunikat do Rady Europejskiej i Parlamentu Europejskiego zatytułowany „Rozwój bliższych stosunków między Indonezją i Unią Europejską”. Dokument określał niektóre z obszarów, które UE chciała zbadać w celu wsparcia Indonezji w jej procesie rozwoju demokracji, ze szczególnym uwzględnieniem takich dziedzin, jak polityka, społeczeństwo, ekonomia, rozwój i ochrona środowiska. Dokument ten miał również zwrócić szczególną uwagę na kwestię praw człowieka, które Unia Europejska nadal uważa za główny warunek i czynnik kształtowania się społeczeństwa demokratycznego oraz trwałego rozwoju. Po pierwszym dialogu politycznym między UE a Indonezją, który odbył się rok później, Unia Europejska przyjęła Krajowy Dokument Strategiczny (Country Strategic Paper-CSP) w 2002 r. Podkreślił on gotowość UE do poprawy stosunków z Indonezją. CSP wzięło również pod uwagę priorytety rządu indonezyjskiego, takie jak dobre zarządzanie i praworządność, problem decentralizacji, walka z ubóstwem, tworzenie miejsc pracy i zmniejszenie niepokojów społecznych. Rozwój i pomoc humanitarna stały się coraz bardziej widocznymi problemami w stosunkach między UE i Indonezją [Cook 2004].

Relacje między Indonezją a Unią Europejską nie zawsze były łatwe. W czasie trwania sytemu Nowego Porządku Indonezja nie mogła otrzymywać finansowego wsparcia. Stawiane warunki przez Europę dotyczące demokracji i praw człowieka były nie do spełnienia dla rządu z jednej strony, z drugiej zaś ideologia nie pozwalała na poddawanie się woli silniejszym państwom europejskim. Na początku lat 90. XX wieku sytuację pogorszyły wybuch protestów w Dili, z którym sprawnie poradziło sobie wojsko. Portugalia jako państwo kolonialne i członek UE oskarżyła reżim Suharto o popełnianie naruszeń praw człowieka, które doprowadziły do nałożenia embarga na Indonezję. Timor Wschodni pozostał więc obszarem niezgody. Po upadku reżimu w 1998 r. Unia Europejska swojego poparcia udzieliła właśnie Timorowi Wschodniemu, uznając za niewłaściwe zachowanie Indonezji, która stłumiła przemocą wybory, przeprowadzone tam 30 sierpnia 1999 r. Unia Europejska nałożyła kolejne embargo, które zostało zniesione dopiero, gdy obie strony doszły do porozumienia. Gdy tylko Timor Wschodni uzyskał niepodległość, relacje europejsko-indonezyjskie zaczęły się poprawiać. UE zaangażowała się w problematykę ruchów etnonacjonalistycznych w Indonezji, szczególnie w kwestię Acehu. Kolejne spięcie pojawiło się w 2007 r., kiedy Unia Europejska nałożyła embargo na indonezyjskie linie lotnicze w czerwcu 2007 r., mimo że w tym czasie żadne linie nie latały nad terytorium europejskim. Państwowe linie lotnicze Garuda odbyły kilka lotów, ale zawiesiły je ze względu na problemy finansowe. UE zniosła ten zakaz w lipcu 2009 r., co zostało bardzo pozytywnie przyjęte przez rząd indonezyjski. W 2014 r. weszła w życie Umowa o Partnerstwie i Współpracy między Indonezją a UE. Indonezja była pierwszym państwem ASEAN, z którym udało się zawrzeć porozumienie. Współpraca ekonomiczna między UE a Indonezją ma priorytetowy charakter. 


\section{ZAKOŃCZENIE}

Indonezja po odzyskaniu niepodległości prowadziła politykę, która miała zapewnić jej niezależność i dobrobyt społeczny. Rządy Sukarno charakteryzowały się antykolonializmem i antyimperializmem, co jest zrozumiałe, jeśli weźmie się pod uwagę holenderską próbę utrzymania dominacji w Indonezji, jak również brak zaufania wobec mocarstw, które początkowo nie uznawały niepodległości indonezyjskiej. Sukarno patrzył podejrzliwie na oba bloki: zachodni i wschodni; chociaż w jego przemówieniach bardzo często pojawią się problem antykolonializmu, to należy dodać, że utrzymywał on kontakty z państwami zachodnimi. Polityka drugiego prezydenta Suharto charakteryzowała się większym pragmatyzmem niż w przypadku Sukarno. Pragmatyzm u niego oznaczał przeorientowanie się na pomoc płynącą z państw zachodnich, a także dostosowanie do wymogów tych państw i instytucji międzynarodowych, m.in. MFW. Działania te oraz skoncentrowanie się na rozwoju ekonomicznym w ciągu kilkunastu lat uczyniło z Indonezji jedną z najszybciej rozwijających się gospodarek na świecie.

Silne rządy Suharto przestały być potrzebne Zachodowi po zakończeniu zimnej wojny. Koniec rywalizacji zimnowojennej i początek kształtowania nowego porządku międzynarodowego, chociaż całkowicie zmienił warunki międzynarodowe, w przypadku Indonezji nie wpłynął aż tak znacząco na jej tożsamość narodową i międzynarodową. W tym czasie zmienił się jednak stosunek Zachodu, przede wszystkim Stanów Zjednoczonych Ameryki do Indonezji, które zaczęły coraz częściej ją krytykować za brak instytucji demokratycznych czy nieprzestrzeganie praw człowieka. Chociaż Suharto nie zawsze zgadzał się z polityką najsilniejszych państw, to nie kierował się on kwestiami ideologicznymi. Wybuch kryzysu azjatyckiego i związane z tym przemiany demokratyczne to moment, który zasadniczo zmienił tożsamość indonezyjską. Od tego czasu Indonezja umacnia swoją pozycję jako największa muzułmańska demokracja na świecie, promuje prawa człowieka i zrównoważony rozwój, występuje w imieniu państw rozwijających się, co więcej - prowadzi podobną politykę jak państwa zachodnie, chociażby w ramach promowania demokracji i praw człowieka. Indonezja przeszła więc drogę od państwa antyzachodniego po prozachodnie w retoryce, pozostając prozachodnie w praktyce. Należy jednak dodać, że Indonezja unika jednoznacznego utożsamiania się z państwami zachodnimi.

\section{BIBLIOGRAFIA}

Acharya, A. 2014. Indonesia Matters: Asia's Emerging Democratic Power, World Scientific, Singapore. Anderson, B. 1990. Indonesian Nationalism Today and in the Future, ,Indonesia”, nr 67, s. 1-11.

Anderson, B. 1999. Language and Power-Exploring Political Cultures in Indonesia, Cornell University Press, Ithaca.

Anwar, D.F. 1994. Indonesia in ASEAN: Foreign Policy and Regionalism, Institute of Southeast Asian Studies, Singapore. 
Anwar, D.F. 2009. A Journey of Change: Indonesia’s Foreign Policy, „Global Asia”, t. 4, nr 3, https://www. globalasia.org (dostęp: 30.09.2017).

Anwar, D.F. 2010. The impact of domestic and Asian regional changes on Indonesian foreign policy, ,Southeast Asian Affairs", nr 1, s. 126-141. DOI: https://doi.org/10.1355/SEAA10H.

Anwar, D.F. 2011. Foreign policy, Islam and democracy in Indonesia, „Journal of Indonesian Social Sciences and Humanities", nr 3, s. 37-54.

Azra, A. 2006. Indonesia, Islam, and Democracy. Dynamics in a Global Context, Equinox Publishing, Jakarta.

Bayat, A. 2007. Islam and democracy. What is a real question, Amsterdam University Press, Amsterdam.

Chandra, A.C. i in. 2010. Hopes and Fears: Indonesia's prospects in an ASEAN-EU Free Trade Agreement, International Institute for Sustainable Development, Winnipeg.

Connelly, A.L. 2015. Sovereignty and the Sea: President Joko Widodo's Foreign Policy Challenges, „Contemporary Southeast Asia", t. 37, nr 1, s. 1-28. DOI: https://doi.org/10.1355/cs37-1a.

Cook, M. 2004. Supporting Democratic Indonesia: British and European Option, Foreign Policy Centre, London.

Drakeley, S. 2005. The History of Indonesia, Greenwood Press, Westport-London.

Emmers, R. 2014. Indonesia's role in ASEAN: A case of incomplete and sectorial leadership, ,The Pacific Review", t. 27, nr 4, s. 543-562. DOI: https://doi.org/10.1080/09512748.2014.924230.

Fic, V.M. 2005. Anatomy of Jakarta Coup: October 1, 1965, Abhinav Publications, New Delhi.

George, K.M. 2010. Picturing Islam: Art and Ethics in a Muslim Lifeworld, Blackwell Publishing, Oxford. Grzywacz, A. 2014. Tożsamość narodowa i polityka zagraniczna Indonezji, Adam Marszałek, Toruń.

Grzywacz, A. 2019. Indonesia's (Inter)national Role as a Muslim Democracy Model: Effectiveness and Conflict Between the Conception and Prescription Roles, „The Pacific Review”. DOI: 10.1080/09512748.2019.1585387.

Gwóźdź, D. 2015. Proces kształtowania się polityki zagranicznej Indonezji po 1998 roku, „Historia i Polityka”, t. 20, nr 13, s. 79-96. DOI: https://doi.org/10.12775/HiP.2015.005.

Hatta, M. 1961. Colonialism and the danger of war, „Asian Survey”, t. 9, nr 1, s. 10-14. DOI: https://doi. org/10.1525/as.1961.1.9.01p15003.

Hughes, J. 2010. Islamic Extremism and the War of Ideas. Lessons From Indonesia, Hoover Institution Press Publication, Stanford.

Indonesia's diplomatic handbook. 2007. International Business Publications, Washington.

Karim, M.F. 2017. Role conflict and the limits of state identity: the case of Indonesia in democracy promotion, ,The Pacific Review”, t. 30, nr 3, s. 385-404. DOI: https://doi.org/10.1080/09512748.2016. 1249908

Kay, L. 2005. Indonesian Public Perceptions of the U.S. and Their Implications for U.S. Foreign Policy, „Issues\&Insight”, t. 5, nr 4, s. 1-43.

Krishna, S. 2009. Globalization and Postcolonialism: Hegemony and Resistance in the Twenty-first Century, Rowman\&Littlefield, Plymouth.

Leifer, M. 1983. Indonesia's Foreign Policy, Allen\&Unwin, London.

Morfit, M. 1981. Pancasila: the Indonesian State Ideology According to the New Order Government, „Asian Survey", t. 21, nr 8, s. 838-851. DOI: https://doi.org/10.1525/as.1981.21.8.01p0298d.

Mortimer, R. 2006. Indonesian Communism Under Sukarno: Ideology and Politics, 1959-1965, Equinox Publishing, Singapore.

Mozingo, D. 2007. Chinese policy toward Indonesia 1949-1967, Equinox Publishing, Singapore.

Murphy, A.M. 2012. Democratization and Indonesian Foreign Policy: Implications for the United States, „Asia Policy”, t. 13, nr 1, s. 83-112. DOI: https://doi.org/10.1353/asp.2012.0011.

Reid, A. 1974. The Indonesian National Revolution 1945-1950, Longman, Melbourne.

Reid, A. 2012. Indonesia rising. The repositioning of Asia's third giant, Routledge, London-New York.

Rüland, J. 2010. Deepening ASEAN cooperation through democratization? The Indonesian legislature and foreign policymaking, ,International Relations of the Asia-Pacific”, t. 10, nr 2, s. 373-402. DOI: https://doi.org/10.1093/irap/lcp010. 
Rüland, J. 2014. The limits of democratizing interest representation: ASEAN's regional corporatism and normative challenges, „European Journal of International Relations”, t. 20, nr 1, s. $237-261$.

Rüland, J. 2017. Democratizing Foreign-Policy Making in Indonesia and the Democratization of ASEAN: A Role Theory Analysis, „TRaNS: Trans-Regional and-National Studies of Southeast Asia”, t. 5, nr 1, s. 49-73. DOI: https://doi.org/10.1017/trn.2016.26.

Shekhar, V. 2018. Indonesia's Foreign Policy and Grand Strategy in the $21^{\text {st }}$ Century: Rise of an Indo-Pacific Power, Routledge, Oxon-New York.

Sukma, R. 1995. The Evolution of Indonesia's Foreign Policy: an Indonesian View, „Asian Survey”, t. 35, nr 3, s. 304-315. DOI: https://doi.org/10.1525/as.1995.35.3.01p00071.

Sukma, R. 2003. Islam in Indonesian Foreign Policy. Domestic Weakness and Dilemma of Dual Identity, Routledge, London-New York.

Sukma, R. 2009. Indonesia-China Relations: The Politics of Reengagement, „Asian Survey”, t. 49, nr 4, s. 591-608. DOI: https://doi.org/10.1057/9780230622623_6.

Sukma, R. 2011. Indonesia Finds a New Voice, „Journal of Democracy”, t. 22, nr 4, s. 110-123. DOI: https://doi.org/10.1353/jod.2011.0057.

Suryadinata, L. 1996. Indonesia's Foreign Policy Under Suharto: Aspiring to International Leadership, Times Academic Press, Singapore.

Vickers, A. 2005. A history of modern Indonesia, Cambridge University Press, Cambridge.

Weinstein, F.B. 2007. Indonesian Foreign Policy and the Dilemma of Dependence, Equinox Publishing, Jakarta.

Wie, T.K. 2002. The Soeharto Era and After: Stability, Development and Crisis 1966-2000, [w:] The Emergence of a National Economy, an Economic, History of Indonesia 1800-2000, H. W. Dick i in. (red.), University of Hawai'i Press, Honolulu.

Youngs, R., Pishchikova, K. 2013. A More Pluralist Approach to European Democracy Support, Carniegie Europe, Brussels.

Yudhoyono, S.B. 2008. Opening Speech by the President of the Republic of Indonesia H. E. Dr. Susilo Bambang Yudhoyono, „Speeches and Proceedings. Bali Democracy Forum”, Department of Foreign Affairs, Jakarta.

\section{RHETORIC AND PRACTICE: FOREIGN POLICY OF INDONESIA TOWARDS THE WEST}

Abstract: The aim of the article is to analyze the relationship between Indonesia and Western countries in two dimensions: rhetorical and practical. The aim of the paper is to answer the question of how Indonesian perception of West has influenced its foreign policy towards the Western countries? The argument of this paper is that the Indonesian criticism of the West has been characterized by its duality: long-term criticism of the West was primarily declarative, therefore - it was rhetoric, not practice. The paper applies the content analysis to investigate rhetoric in the foreign policy; then the narrative was compared with political practice before and after the democratization of Indonesia. The article is divided into four parts. After the introduction, Indonesian foreign policy is discussed before and after democratic changes. The paper ends with the conclusion. Adoption of a long-term perspective provides the overview of changes in the foreign policy of Indonesia - from anti-Western to pro-Western country in rhetoric and pro-Western in practice.

Keywords: Indonesia, foreign policy, West, rhetoric 


\section{BIOGRAM}

Anna Grzywacz, doktor nauk społecznych w zakresie nauk o polityce, absolwentka studiów pierwszego i drugiego stopnia (specjalizacja wschodnioazjatycka) w Instytucie Stosunków Międzynarodowych Uniwersytetu Warszawskiego. Zainteresowania naukowe: stosunki międzynarodowe w Azji Południowo-Wschodniej, ze szczególnym uwzględnieniem polityki zagranicznej Indonezji i Singapuru, a także kulturowych aspektów polityki państw tego regionu, postkolonializm. Ostatnie publikacje: Polityka zagraniczna Singapuru w regionie Azji i Pacyfiku, Warszawa 2019; Indonesia's (Inter)national Role as a Muslim Democracy Model: Effectiveness and Conflict Between the Conception and Prescription Roles, "The Pacific Review", 2019, DOI: 10.1080/09512748.2019.1585387. Kontakt e-mail: anna.y.grzywacz@gmail.com. 